\title{
Pneumologia
}

\section{Influenza vaccine in COVID-19 patients: Who?, why?, when?}

Raluca loana Dospinescu Arcana ${ }^{1 * *}$, Radu Crișan-Dabija ${ }^{1,2}$, Anda Tesloianu², Daniela Robu Popa ${ }^{2 *}$, Oana-Elena Rohozneanu ${ }^{1 * *}$, Ioana Buculei ${ }^{1 * *}$, Sabina Antoniu ${ }^{1,2}$, Antigona Trofor $^{1,2}$

${ }^{1}$ Grigore T. Popa" University of Medicine and Pharmacy, laşi, Romania

${ }^{2}$ Clinical Hospital of Pulmonary Diseases, laşi, Romania

Abstract

English:

Considering the increased prevalence of influenza infections in the cold season and the pandemic evolution of severe acute respiratory syndrome-CoV-2 (SARS-CoV-2), the medical staffs are facing potential viral co-infection with SARS-CoV-2 and influenza virus. Both viruses belong to the category of ribonucleic acid (RNA) viruses, having common structural features, causing a similar immune response, with a related mode of transmission and with both respiratory and general symptoms. SARS-CoV-2 and influenza viruses cause contagious infections and the protective measures against them are the same: wearing masks in crowded spaces, proper hand hygiene and avoiding crowded places. Co-infections with influenza $A$ and $B$ viruses and SARS-CoV-2 virus involve additional precautions regarding the therapeutic and evolution approach. Studies show that patients who have been vaccinated against influenza have developed milder forms of confirmed SARS-CoV-2 infection. In elderly patients, increased influenza vaccination coverage has shown to be associated with a decrease in mortality rate and also reduced the heavy impact of double infection. The Influenza vaccine can trigger early immune mechanisms in order to facilitate early detection of SARS-CoV-2 as well as its clearance. Influenza vaccination should now be seen, more than ever, as a strategy to combat the growing SARS-CoV-2 pandemic, especially in vulnerable populations (elderly and people with associated comorbidities).

Keywords

\section{Vaccinarea antigripală la pacienții cu COVID-19. Cine? de ce? când?}

Rezumat

Romanian:

Având în vedere prevalența crescută a infecțiilor gripale în sezonul rece și evoluția pandemică a afectării cu coronavirusul sindromului respirator acut sever 2 (SARS-CoV-2), personalul medical se confruntă cu situații noi, precum asocierea celor două infecții la același pacient. Ambele virusuri fac parte din categoria de ARN virusuri, prezentând caracteristici comune structurale, determinând un răspuns imun asemănător, cu modalitate de transmitere similară și cu prezentare clinică respiratorie și nespecifică în ambele cazuri. SARS-CoV-2 și virusul Influenza determină infecții contagioase iar principalele măsuri de protecție sunt aceleași: purtarea măștilor în spații aglomerate, igiena corespunzătoare a mâinilor și evitarea supraaglomerărilor. Co-infecțiile cu virusurile gripale A și B și cu virusul SARS-CoV-2 implică precauții sumplimentare în ceea ce privește abordarea terapeutică și evolutivă. În literatura de specialitate se regăsesc dovezi ale faptului că pacienții care au fost vaccinati antigripal, au dezvoltat forme mai ușoare de infectie confirmată cu SARS-CoV-2. La pacienții vârstnici s-a demonstrat faptul că o acoperire vaccinală antigripală mai crescută se asociază cu o scădere a ratei de mortalitate, vaccinarea antigripală reducând gravitatea impactului dublei infectări. Vaccinarea antigripală poate declanșa mecanisme imune timpurii care să faciliteze detecția virusului SARS-CoV-2 și clearence-ul acestuia. Vaccinarea antigripală ar trebui privită acum, mai mult ca oricând, ca o strategie de luptă împotriva asaltului pandemiei SARS-CoV-2, în special la populații vulnerabile (vârstnici și persoane cu comorbidități asociate).

Cuvinte-cheie

SARS-CoV-2 $\cdot$ virusul antigripal $\cdot$ vaccinare

${ }^{*}$ Corresponding author: Daniela Robu Popa

E-mail: rb_dana@yahoo.com

${ }^{\star *} P h D$ Student.

2 Open Access. () 2021 Arcana et al., published by Sciendo

(c) Br-NC-ND This work is licensed under the Creative Commons Attribution-NonCommercial-NoDerivs 4.0 License. 


\section{Introduction}

Severe acute respiratory syndrome-CoV-2 (SARS-CoV-2) is a new strain of coronavirus with respiratory tropism that can cause severe pneumonia leading to acute respiratory distress syndrome (ARDS) and death. The disease caused by the SARS-CoV-2 virus, Coronavirus disease 2019 (COVID-19), was first reported in the Chinese city of Wuhan in December 2019 , when medical staff detected several cases of atypical pneumonia (1).

Subsequently, within a few months of the first reports, SARSCoV-2 has spread worldwide, reaching a pandemic level, which led to a massive disease burden and many deaths causing huge pressure on the medical and socio-economic system.

Following the emergence of this new virus, a series of investigations was carried out, which discovered ribonucleic acid (RNA)-type virus as the etiological agent, which belongs to the same coronavirus family that caused Severe Acute Respiratory Syndrome (SARS) and the Middle East Respiratory Syndrome (MERS) epidemic in 2003 and 2012, respectively (2).

A Coronaviridae family is a large group of viruses that cause disease in both animals and humans. Seven types of human coronaviruses are pathogens primarily with respiratory tropism: 229E, NL63, OC43, KHU1, MERS-CoV, SARS-CoV and SARSCoV-2. MERS-CoV, SARS-CoV and SARS-CoV-2 belong to the genus Betacoronavirus and all have high mutation rates that lead to viral genetic diversity, plasticity and adaptability to invade a wide range of hosts (3).

SARS-CoV-2, like other coronaviruses, has S-glycoproteins on the membrane that plays an important role in binding the virus with the angiotensin-converting enzyme 2 (ACE2) receptor. The ACE2 receptor is an intramembrane receptor found on type II pneumocytes, where the virus can replicate. As the viral load increases inside the alveolar cell, the alveolar epithelial cell will release the newly replicated viral RNA (4). On the other hand, infection with influenza viruses is a characteristic of the cold season and can cause epidemics and a substantial socio-economic crisis worldwide. The World Health Organization (WHO) reports approximately 650,000 deaths annually, with an annual disease rate of $5-10 \%$ in adults and $20-30 \%$ in children. Thus, the risk of a pandemic with influenza viruses and the burden of seasonal influenza on the health and economic system suggest the need for studies on the impact and prevention of influenza virus infection $(5,6)$.

Until now, there are four types of influenza A, B, C and D. Among these, influenza $A$ and $B$ cause seasonal flu. Type $A$ virus has different combinations of hemagglutinin (HA) and neuraminidase proteins and is known to have 18 subtypes of $\mathrm{HA}$ and 11 subtypes of neuraminidase. Public health experts are mainly concerned about the type A influenza virus because usually new and virulent type $A$ strain is the cause of pandemics (7).

Considering the high prevalence of the influenza virus in the cold season and the pandemic evolution of SARS-CoV-2, we are facing the possibility of co-infection with both Influenza virus and SARS-CoV-2. Both cause contagious diseases with the airborne transmission, through droplets and fomites and both diseases exhibit similar symptoms, mainly respiratory, imposing the same protective measures such as: wearing masks in crowded places, thorough hand hygiene and avoiding crowded places. As to the differences between the two diseases, WHO states that SARS-CoV-2 has a higher rate of infectiousness and can lead to more severe clinical manifestations in vulnerable patients. Moreover, SARS-CoV-2 has a longer period of latency compared to Influenza, a time period in which these patients are highly contagious $(8,9)$.

Several studies tried to determine the prevalence of coinfection in patients with SARS-CoV-2. A study by Wang et al. (10) found that among 104 patients infected with SARSCoV-2, $1.94 \%$ had also an overlay infection with Influenza virus type $A$.

Another case study that was conducted in China reported the case of a 69-year-old patient who was diagnosed with both SARS-CoV-2 and Influenza virus infections. At the time of admission, the main complaints were fever and dry cough. The thoracic computed tomography (CT) scan showed ground-glass opacities in the right lower lobe. At first, the patient was negative to the reverse transcription polymerase chain reaction (RT-PCR) test for SARS-CoV-2 and positive for Influenza virus, and within a week the RT-PCR for SARS-CoV-2 became positive (11).

Also, a study conducted by Cuadrado et al. (12) in Spain reported that four patients, who developed respiratory symptoms and had other comorbidities, were found to have co-infection with both SARS-CoV-2 and Influenza virus.

A study in Iran done by Khodamoradi et al. (13) investigated that four patients admitted with a major respiratory complaint, which is highly expressive for SARS-CoV-2 infection, were found positive for both SARS-CoV-2 and Influenza infection.

Ma et al. (14) conducted a study in Wuhan, China, enrolling 93 positive COVID-19 patients, of which $47.3 \%$ also had influenza A virus infection and $2.2 \%$ had influenza $B$ virus infection. They observed an exacerbation of the immune response with an important neutrophilic activation and a faster and more severe onset of a fulminant cytokine storm, which made the clinical course in patients with co-infection to be more severe and with more complications (shock, ARDS, acute renal failure and multiple organ failure). In addition, more severe heart injury was observed in critically ill patients with co-infection, and in terms of survival, $50 \%$ of the patients who died had both types of viral infection. 
Co-infections with Influenza virus type A or B and with SARSCoV-2 entail additional precautions regarding the therapeutic approach and also the clinical evolution $(15,16)$.

As for Influenza viruses, we are fortunate to have access to antiviral treatments and prophylactic vaccines, with a beneficial impact on patients from many perspectives.

At the moment, there is no vaccine against SARS-CoV-2 that has a good rate of success. Still, the therapeutic approach for SARS-CoV-2 infected patients remains mainly symptomatic (8).

The seasonal flu vaccine reduces morbidity and mortality and the Center for Disease Control and Prevention (CDC) recommends vaccination starting with the age of 6 months. However, the high-risk populations ( $>65$ years old, pregnant women, patients with obstructive pulmonary disease, cardiovascular disease, diabetes, HIV+/AIDS, cancer, chronic renal disease), as well as the medical staff and the personnel working in retirement homes, should have priority for vaccination $(17,18)$.

\section{Influenza vaccination in vulnerable patients}

As of now, COVID-19 is an unpredictable disease, which can present itself under a variety of clinical forms in completely asymptomatic patients, patients with confirmed mild, moderate, or severe infection with SARS-CoV-2, patients with moderate or severe pneumonia that can progress to ARDS and can eventually need intubation and mechanical ventilation (19).

It is well known that severe cases of pneumonia with SARSCoV-2 develop especially in the elderly or in individuals with comorbidities. For instance, individuals with metabolic diseases (diabetes), cardiovascular diseases (arterial hypertension, chronic heart disease, ischemic heart disease), obstructive pulmonary diseases, chronic kidney diseases and history of malignancy pose the highest risk. At the same time, individuals $>65$ years old have a higher risk of severe complications as well as a higher rate of morbidity and mortality. Thus, the Influenza vaccine has an important role in protecting such vulnerable patients (20).

The Influenza vaccine in patients with COVID-19 and cardiovascular disease, especially in those with coronary artery disease, has a shielding effect by reducing the risk of acute myocardial infarction and the risk of acute cardiovascular events (21).

The results of a study done by Zanettini et al. (22), which analysed the protective effect of the Influenza vaccine, regarding mortality in patients $>65$ years old showed that there was a reduction by $28 \%$ on the mortality in this category of patients. This was correlated with an increase of vaccination coverage by $10 \%$.
One study in Italy done by Marín-Hernández et al. (23), which analysed the same protective effect of the Influenza vaccine in elderly patients with COVID-19, found that the patients who had taken their flu vaccine had a lower rate of mortality, thus it can be concluded that influenza vaccination can reduce the severe impact of this co-infection.

\section{Influenza vaccination coverage rates}

The most comprehensive influenza vaccine coverage is a real success in preventive medicine, and increased compliance is in direct proportion with the benefits on medical and socioeconomical levels. However, influenza vaccination coverage rates differ across Europe and the world. WHO recommends a $75 \%$ threshold for influenza vaccination in elderly patients, given that this category is prone to the development of severe forms of viral infections, which can lead to death. The age limit for vaccination recommendations differs considerably. Though an age-limit of 65 years is considered optimal in Europe, but in Germany, Hungary, Iceland or Greece, the agelimit is 60 years, and in the USA the cut-off is set at 50 years. This last aspect probably contributes to a statistically higher vaccine coverage in the USA than in other European countries for this risk category (24).

A study by Fiona et al. (25) published last year examined the contributing factors to suboptimal influenza vaccine coverage in elderly patients. Thus, a key aspect is the hesitation of the patients derived mainly from incorrect or insufficient information about the benefits of immunisation. Another problem is the insufficient awareness of the potential severity of the infection which leads to a lack of importance given among the general population. This, together with a lack of knowledge of the disease, with an underestimation of the potential severity, causes a large part of the population to see influenza vaccination as unjustified. At the same time, there is a general lack of confidence in the published efficacy data as well as a lack of confidence in the effectiveness of the vaccine. Patient education becomes essential to achieve the best possible compliance. Data from Europe are variable, showing an influenza vaccination rate between $0.03 \%$ and $76.3 \%$, with an average of $34.4 \%$. Vaccine coverage of $75 \%$ has been recorded only in Scotland, in accordance with WHO recommendations (25).

According to a study by Sheick et al. (26), the median coverage rates for influenza vaccination analysed in elderly people over a 10 year period vary between countries. As such, in Belgium, the coverage rate is estimated at $66.1 \%$ while it is $71.6 \%$ in the United Kingdom and $56.1 \%$ in Spain. A lower coverage rate was found in Poland at $4.3 \%$ and in Romania at $14.9 \%$. For patients with chronic diseases at high-risk and immunocompromised patients, there is little data available 
regarding coverage rates for influenza vaccination. Available data suggests that this category is generally under-vaccinated even in countries with well-developed healthcare systems. A study conducted in the US by Doherty et al. (27) found that patients with diabetes mellitus had a coverage rate of $41 \%$, far below the recommended target.

Another study by Lu et al. (28), which analysed the coverage rate for influenza vaccination in the US among adults with chronic diseases aged between 18 years and 64 years old, found a rate of $49.5 \%$ for the $2012-2013$ season.

Pregnant women represent another category that is considered high risk. The severity of complications that can occur if a pregnant woman develops a viral infection is directly proportional to the development of the pregnancy. Even though the influenza vaccine adds many benefits both to the mother and foetus, the coverage rate is under 40 in the US (29). Influenza vaccination among pregnant women is recommended in almost all of the European countries, except for The Netherlands and Bulgaria (26).

Regarding healthcare workers, the coverage rates for influenza vaccination vary from $5 \%$ to $90 \%$ across the globe. The coverage rate was estimated to be $<40 \%$ in Europe and $>77 \%$ in the US for the $2014-2015$ season. In Romania, the coverage rate was $63.9 \%$ for the $2011-2012$ season, but the numbers are decreasing (30).

\section{The immune response and cross-immunisation}

From a structural standing point of view, there is a resemblance between the SARS-CoV-2 virus and the Influenza virus and therefore one could explain, at least partially, the similarities in the immune response.

The innate immune system is sensitive in detecting the potentially pathogenic components, triggering the release of alpha-interferon 1 (IFN-1) and inflammatory cytokines through a series of specific mechanisms $(31,32)$.

In infectious respiratory diseases, caused by viruses such as SARS-CoV-2 and Influenza, the cytokine storm is considered to be one of the most frequent causes of acute respiratory distress syndrome (ARDS). This happens secondary to an increase in vascular permeability and due to perfusion of the fluid and blood components into the alveoli. Studies show that Interleukin 6 (IL-6), Interleukin 10 (IL-10), Interleukin 18 (IL-18), Interleukin 33 (IL-33), Tumour Necrosis Factor-alpha (TNF alpha) and Interferongamma (IFN gamma) play an important role in the aetiology of the cytokine storm, with IL-6 being the most implicated one. At the same time, the production of pro-inflammatory mediators results from TNF alpha and Interleukin 1 (IL1) stimulating the signalling pathways and producing an amplification loop (33).
As well, both SARS-CoV-2 and Influenza viruses activate the immune mechanisms through Toll-like receptor 7 (TLR-7). In both these cases, epithelial respiratory cells, alveolar macrophages and neutrophils represent cellular targets of these viruses. In the infections caused by ribonucleic acid (RNA) viruses, the immune response is triggered by a series of receptors found in both categories: toll-like receptors (TLRs), particularly TLR3 and TLR-7, and retinoic acidinducible gene-I-like receptors (RIG-I-like) have the capacity of detecting the nucleic acids of RNA viruses. $(34,35)$.

Even if the Influenza vaccine is recommended to patients aged $\geq 65$, it has been proven that its effectiveness is suboptimal in this category due to the consequences of the immunosenescence process. The Influenza virus interacts with mediators of the innate immune system, such as TLR-7 and nucleotide oligomerisation domain (NOD)-like receptors (NLRs, NLR Family Pyrin Domain Containing 3 - NLRP3, NOD2), resulting in activation of specific immune mechanisms. Impaired response of TLRs can lead to important damage in cellular as well as in humoral immunity. At a cellular level, a decrease in both numbers and functionality of $T$ lymphocytes CD8+ and also an inadequate and insufficient inflammatory response can be noticed (36).

What is interesting to take into account is the individual's immune response according to the severity of the disease. It is well known that SARS-CoV-2 can avoid early immune response mechanisms and, at the same time, once they are activated, the triggering of the cytokine storm can be severe (19). Influenza vaccination could act as an unspecific immune stimulator in patients confirmed with SARS-CoV-2 before the virus has had a chance to invade the cells. This is possible through early activation of the immune system by the vaccine, which will help in the early detection of SARS-CoV-2. Additionally, the Influenza vaccine will maintain an active immune system through TLRs (19).

A study by Jehi et al. (37) promotes the same key aspect of unspecific immune activation which appears secondary to vaccination. In this study, the authors tried to create predictive statistical analysis to anticipate the individualised risk of a positive test for SARS-CoV-2 infection. Thus, the risk of having a positive test was lesser in patients who had taken their flu shots, and this is probably due to sustained activation of TLR-7 by the influenza vaccine. TLR-7 plays a crucial role in the attachment of respiratory, single strain ARN viruses, such as SARS-CoV-2, thus being able to explain a form of cross-protection (37).

Therefore, the Influenza vaccine can trigger early immune mechanisms in order to facilitate early detection of SARSCoV-2 as well as its clearance (37).

It seems that the live attenuated influenza vaccine (LAIV) has a higher efficacy in stimulating the memory of innate immunity. This could prevent the development of SARS- 
CoV-2 pneumonia (23). In addition, LAIV stimulates the innate immunity and offers a degree of protection against infection with SARS-CoV-2, due to suppression of the innate immunity by SARS-CoV-2 (19).

A study in Australia analysed the specific cellular and humoral immune response in patients with mild forms of COVID-19 at various stages of the disease and convalescence. Thus, a growing number of antibody-secreting cells (ASCs), follicular helper T cells (TFH cells), activated CD4 and CD8 lymphocytes and $\lg M$ and $\lg G$ antibodies were found. Activation of CD8 + T lymphocytes can be observed by analysing CD38 and Human Leukocyte Antigen - DR isotype (HLA-DR) co-expression. This immune response is similar to that which occurs during influenza infection or as a result of influenza vaccination. In this case, an increase in the number of ASCs, cells that secrete specific antibodies, and an increase in the number of activated TFH cells (cTFH cells) were found, the last one being demonstrated by increased CD38 and HLA-DR coexpression (38-40).

The similarities in the immune system in terms of the presence of secretory Immunoglobulin A $(\operatorname{IgA})$ can be observed both in the SARS-COV-2 virus after infection and influenza vaccination. Secretory IgA plays an important role in early immune defence against respiratory pathogens. In addition, a direct proportionality has been demonstrated between secretory IgA levels and the severity of SARSCoV-2 infection. IgAs can be a useful indicator in the analysis of patients' immune responses and can be used in stratifying sections of the population at risk of developing severe forms of COVID-19 $(41,42)$.

Quantitative assessment of IgA could also serve as a tool to divide the population into different risk categories and depending on the degree of risk to determine and prioritise vaccine delivery (42).

Another important aspect is the concept of crossimmunisation. It refers to the protection obtained - acquired immunisation from a previous infection which could be beneficial in the fight against other pathogens. Numerous studies have shown the existence of antibodies against an antigenic protein called HA. A specific portion of this envelope glycoprotein is conserved in many strains of influenza viruses, and recent studies show that some coronaviruses possess similar HAs as a result of mutations. In addition, cross-immunisation in influenza vaccinated patients requires increased activation of the innate immune system. These aspects were demonstrated in a study carried out by Zeng et al. in the Netherlands among patients who were given the quadrivalent inactivated influenza vaccine. It was observed that, following the interaction of the immune system cells of these patients with the SARS-CoV-2 virus, the cytokine response was profoundly improved. At the same time, the confirmed SARS-CoV-2 infection was greatly reduced among hospital staff who had been previously vaccinated against influenza $(19,31,43)$.

\section{The protective effect of influenza vaccination}

Influenza vaccination develops a specific immune response that may be beneficial in the fight against SARS-CoV-2 infection. There has been an increase in Integrin alpha $X$ and T-cell-specific T-box transcription factor T-bet expression, which means a higher activation of memory B lymphocytes, followed by the synthesis of specific and nonspecific antibodies and potentially protective in other types of viral damage (44). A study in Brazil conducted by Fink et al. (45) investigated the protective effect of influenza vaccination in patients already confirmed positive with SARS-CoV-2 infection, observed a decrease of $17 \%$ in mortality risk, a decrease of $8 \%$ in the risk of hospitalisation in intensive care units and a decrease of $18 \%$ in the risk of intubation and mechanical ventilation, compared with patients who were not vaccinated. One possible explanation could be the triggering of innate immune mechanisms following vaccination, leading to more effective SARS-CoV-2 viral clearance, and preventing the severe cytokine storm encountered in severe cases. The study concludes that influenza vaccination reduces significantly the severity of COVID-19 disease.

A prospective study conducted at a clinic in Cleveland, Ohio, by Jehi et al. (37), in which 11,672 patients were enrolled, provided valuable information regarding the risk of SARS-CoV-2 infection in Influenza vaccinated patients. It was observed that $93.9 \%$ of all non-COVID patients (5940) were vaccinated against influenza, while among COVID-19 positive patients (384), only $6.1 \%$ were vaccinated. This study concluded that influenza vaccination provided additional protection for patients.

At the same time, patients who have received the flu vaccine before a possible SARS-CoV-2 infection may have milder forms of COVID-19. A possible reason could be found in the differences in the quality and quantity of the immune response caused by the flu vaccine. The authors hypothesise a crossimmunity that could be protective in terms of the evolution and severity of SARS-CoV-2 infection (46).

$\mathrm{Li}$ et al. (47) showed in a recent study that mass influenza vaccination determines a lower number of confirmed COVID-19 patients, especially among the elderly, with associated comorbidities. The study enrolled suspected and confirmed patients from China from January 23 to March 29, 2020, when the flu season was over. Given that the clinical picture of the two diseases largely overlaps, especially in the flu season, it is difficult to quickly and accurately distinguish between the two types of viral diseases, so patients with respiratory symptoms were hospitalized in sectors of suspects of COVID-19 disease, 
where the risk of cross-contamination was very high. The authors demonstrated that a mass influenza vaccination campaign had a positive effect in the management of patients with nonspecific symptoms of lower respiratory tract infection, lowering the rate of hospitalisation of patients with non-specific symptoms, potentially at-risk of developing the COVID-19 during their admission at the hospital. Also, a high rate of influenza vaccination can ease the efforts to control the COVID-19 outbreak (47).

\section{Conclusions}

Now, Influenza vaccination can be seen more than ever as a strategy to combat the growing evolution of the COVID-19 pandemic, addressing certain vulnerable categories, in which most cases of SARS-CoV-2 infection have been observed: the elderly and patients associated with comorbidities. A special category is represented by pregnant women, and the decision to vaccinate them against influenza must be made quickly and must be done before starting of the cold season (48).

Data from a study by Grech and Borg (49) state that high coverage of influenza vaccination will enhance immunity and reduce susceptibility to other infections, including SARS-CoV-2, thus leading to a lower number of hospitalisations and to the preservation of medical resources for other severe cases.

Another important aspect highlighted in a study by Thindwa et al. (50) is that the influenza vaccination will increase the specificity of the surveillance of patients with confirmed SARS-CoV-2 infection. Even if there are similarities in the clinical picture between the two pathologies, in the case of influenza vaccinated patients, it could be easier to notify the specific symptoms of COVID-19, thus facilitating targeted therapy in pacients with SARS-CoV-2 infection.

Influenza vaccination brings multiple benefits, both in terms of health and economics. So, it must remain a priority given that it reduces the negative impact of COVID-19 on patients' status, especially during an upward evolution of the COVID-19 pandemic. As well, influenza vaccination can avoid overburdening health services with patients affected by influenza infections, while also allowing better management of the COVID-19 cases (51).

Questions that emerge given the current status quo:

1. When is influenza vaccination appropriate in the 20202021 season? Is it best to be done as soon as possible?

2. What are the categories that should have priority for Influenza vaccination: vulnerable populations/at-risk for COVID-19?

3. When is the best time to administer the influenza vaccine to patients who have been infected with SARS-CoV-2? 14 days after the last PCR test negative/asymptomatic?
Questions that are raised for the future:

1. Will a booster dose of the influenza vaccine be needed in the 2020-2021 season? To whom/when?

2. When the COVID-19 vaccine is available, what will be the vaccination sequence for those who have not received influenza vaccine/vaccinated over 6 months?

3. Should we expect 'cross-reactions' between the influenza vaccine and the COVID-19 vaccine?

4. What about vaccinating COVID-19 patients who already had the COVID-19 disease in early 2020 ?

\section{References}

1. Ahn D-G, Shin H-J, Kim M-H, Lee S, Kim H-S, Myoung J, et al. Current status of epidemiology, diagnosis, therapeutics, and vaccines for novel coronavirus disease 2019 (COVID-19). Journal of Microbiolog and Biotechnology. 2020;30(3): 313-324

2. Lu R, Zhao X, Li J, Niu P, Yang B, Wu H, et al. Genomic characterisation and epidemiology of 2019 Novel Coronavirus: implications for virus origins and receptor binding. Lancet. 2020;395: 565-74.

3. Walls AC, Park Y-J, Tortorici MA, Wall A, McGuire AT, Veesler D. Structure, function, and antigenicity of the SARS-CoV-2 spike glycoprotein. Cell. 2020;181(2): 281-292.e6.

4. Shah A, Kashyap R, Tosh P, Sampathkumar P, O'Horo JC. Guide to understanding the 2019 novel coronavirus. Mayo Clinic Proceedings. 2020;95: 646-652.

5. Lee VJ, Ho ZJM, Goh EH, Campbell H, Cohen C, et al.; WHO working group on influenza burden of Disease. Advances in measuring influenza burden of disease. Influenza and Other Respiratory Viruses. 2018;12: 3-9.

6. Who.int. 2021. Up to 650000 people die of respiratory diseases linked to seasonal flu each year. [online] Available at: https:// www.who.int/news/item/13-12-2017-up-to-650-000-people-dieof-respiratory-diseases-linked-to-seasonal-flu-each-year.

7. CDC (Center for Disease Control and Prevention). Influenza Type A Viruses; 2017b. https://www.cdc.gov/flu/avianflu/influenza-a-virus-subtypes.htm.

8. World Health Organization. Coronavirus disease (COVID-19) pandemic. Available from: https://www.who.int/emergencies/diseases/novel-coronavirus2019 [Accessed 25th October 2020].

9. Similarities and Differences between Flu and COVID-19. Centers for Disease Control and Prevention; 2020. Available from: https://www.cdc.gov/flu/symptoms/flu-vs-COVID-19.htm. [Accessed 16th November 2020].

10. Wang $M$, Wu Q, Xu W, Qiao B, Wang J, Zheng $H$, et al. Clinical diagnosis of 8274 samples with 2019-novel coronavirus 
in Wuhan. Medrxiv; Februay 2020. doi:10.1101/2020.02.12.200 22327.

11. Wu X, Cai $Y$, Huang $X, Y u X$, Zhao L, Wang F, et al. Co-infection with SARS-CoV-2 and influenza $A$ virus in patient with pneumonia, China. Emergency Infectious Diseases. 2020;26(6): 1324-1326.

12. Payan EC, Montagud-Marrahi E, Torres-Elorza M, Bodro M, Blasco M, Poch E, et al. SARS-CoV-2 and influenza virus co-infection. Lancet. 2020;395(10236): e84.

13. Khodamoradi Z, Moghadami M, Lotfi M. Co-infection of coronavirus disease 2019 and influenza A: a report from Iran. Archives of Iranian Medicine. 2020;23(4): 239-243.

14. Ma S, Lai X, Chen Z, Tu S, Qin K. Clinical characteristics of critically ill patients co-infected with SARS-CoV-2 and the influenza virus in Wuhan, China. International Journal of Infectious Diseases. 2020;96: 683-687.

15. Xing Q-S, Li G-J, Xing Y-H, Chen T, Li W-J, Ni W, et al. Precautions are Needed for COVID-19 patients with coinfection of common respiratory pathogens. 2020; doi:10.1101/2020.02.29.2002 7698.

16. Singh B, Kaur P, Reid RJ, Shamoon F, Bikkina M. COVID-19 and influenza co-infection: report of three cases. Cureus. 2020;12(8): e9852.

17. Gostin L, Salmon D. The dual epidemics of COVID-19 and influenza. Published Online: June 11, 2020. doi:10.1001/ jama.2020.10802.

18. People at High Risk of Flu. Centers for disease control and prevention; 2020. Available from: https://www.cdc.gov/flu/highrisk/ index.htm. [Accessed 16th November 2020].

19. Eldanasory OA, Rabaan AA, Al-Tawfiq JA. Can influenza vaccine modify COVID-19 clinical course? Travel Medicine and Infectious Disease. 2020;37: 101872.

20. Zhou F, Yu T, Du R, Fan G, Liu Y, Liu Z, et al. Clinical course and risk factors for mortality of adult inpatients with COVID- 19 in Wuhan, China: a retrospective cohort study. Lancet. 2020;395: 1054-1062.

21. Behrouzi B, Araujo Campoverde M, Liang K, Talbot HK, Bogoch II, McGeer A, et al. Influenza vaccination to reduce cardiovascular morbidity and mortality in patients with COVID-19. Journal of the American College of Cardiology. 2020;76(15): 1777-1794.

22. Zanettini C, Omar M, Dinalankara W, Imada EL, Colantuoni E, Parmigiani G, et al. Influenza vaccination and COVID-19 mortality in the USA. MedRxiv 2020;2020. doi:10.1101/2020.06.24.201 29817. 06.24.20129817.

23. Marín-Hernández D, Schwartz RE, Nixon DF. Epidemiological evidence for association between higher influenza vaccine uptake in the elderly and lower COVID-19 deaths in Italy [published online ahead of print, 2020 Jun 4]. Journal of Medical Virology. 2020; doi:10.1002/jmv.26120.

24. Blank P, Szucs T. Increasing influenza vaccination coverage in recommended population groups in Europe. Expert Review of Vaccines, 2009;8(4): 425-433.
25. Ecarnot F, Maggi S, Michel JP. Strategies to Improve Vaccine Uptake throughout Adulthood. Interdiscip Top Gerontol Geriatr. 2020;43:234-248. doi: 10.1159/000504486. PMID: 32305979.

26. Sheikh S, Biundo E, Courcier S, Damm O, Launay O, Maes E, et al. A report on the status of vaccination in Europe. Vaccine. 2018;36(33): 4979-4992.

27. Doherty M, Schmidt-Ott R, Santos J, Stanberry L, Hofstetter A, Rosenthal S, et al. Vaccination of special populations: protecting the vulnerable. Vaccine. 2016;34(52): 6681-6690.

28. Lu P, O'Halloran A, Ding H, Srivastav A, Williams W. Uptake of influenza vaccination and missed opportunities among adults with high-risk conditions, United States, 2013. The American Journal of Medicine. 2016;129(6): 636.e1-636.e11.

29. Ellingson MK, Dudley MZ, Limaye RJ, Salmon DA, O'Leary ST, Omer SB. Enhancing uptake of influenza maternal vaccine. Expert Review of Vaccines. 2018; doi:10.1080/14760 584.2019.1562907.

30. To K, Lai A, Lee K, Koh D, Lee S. Increasing the coverage of influenza vaccination in healthcare workers: review of challenges and solutions. Journal of Hospital Infection. 2016;94(2): 133-142.

31. Zeng Q, Langereis MA, van Vliet ALW, Huizinga EG, de Groot RJ. Structure of coronavirus hemagglutinin-esterase offers insight into corona and influenza virus evolution. Proceedings of the National Academy of Sciences of the USA. 2008;105(26): 9065-9069.

32. Abdella R, Aggarwal M, Okura T, Lamb RA, He Y. Structure of a paramyxovirus polymerase complex reveals a unique methyltransferase-CTD conformation. Proceedings of the National Academy of Sciences of the USA 2020;117(9): 4931-4941.

33. Khorramdelazad $H$, Kazemi $M H$, Najafi A, Keykhaee $M$, Emameh RZ, Falak R. Immunopathological similarities between COVID-19 and influenza: Investigating the consequences of coinfection. Microbial Pathogenesis. 2021;152: 104554.

34. Stegemann-Koniszewski S, Behrens S, Boehme JD, Hochnadel I, Riese P, Guzmán CA, et al. Respiratory influenza A virus infection triggers local and systemic natural killer cell activation via toll-like receptor 7. Frontiers in Immunology. 2018;9: 245.

35. Poulas K, Farsalinos K, Zanidis C. Activation of TLR7 and innate immunity as an efficient method against COVID-19 pandemic: imiquimod as a potential therapy. Frontiers in Immunology. 2020;11. doi:10.3389/fimmu.2020.01373.

36. Lambert ND, Ovsyannikova IG, Pankratz VS, Jacobson RM, Poland GA. Understanding the immune response to seasonal influenza vaccination in older adults: a systems biology approach. Expert Review in Vaccines. 2012;11: 985-994.

37. Jehi L, Ji X, Milinovich A, Erzurum S, Rubin B, Gordon S, et al. Individualizing risk prediction for positive COVID-19 testing: results from 11,672 patients. Chest. 2020; doi:10.1016/j. chest.2020.05.580.

38. Thevarajan I, Nguyen THO, Koutsakos M, Druce J, Caly L, Van de Sandt CE, et al. Breadth of concomitant immune 
responses prior to patient recovery: a case report of non-severe COVID-19. Nature Medicine. 2020;26: 453-455.

39. Ellebedy AH, Jackson KJ, Kissick HT, Nakaya HI, Davis CW, Roksin $\mathrm{KM}$, et al. Defining antigen-specific plasmablast and memory B cell subsets in human blood after viral infection or vaccination. Nature Immunology. 2016;17: 1226-1234.

40. Koutsakos M, Wheatley AK, Loh L, Clemens EB, Sant S, Nüssing $\mathrm{S}$, et al. Circulating TFH cells, serological memory, and tissue compartmentalization shape human influenza-specific $B$ cell immunity. Science Translational Medicine. 2018;10(428): 1-15.

41. Gould V, Francis JN, Anderson KJ, Georges B, Cope AV, Tregoning JS. Nasal IgA provides protection against human influenza challenge in volunteers with low serum influenza antibody titre. Frontiers in Microbiology, 2017;8: 900.

42. Varadhachary A, Chatterjee D, Garza J, Garr RP, Foley C, Letkeman AF, et al. Salivary anti-SARS-CoV-2 IgA as an accessible biomarker of mucosal immunity against COVID-19. medRxiv [Preprint]. 2020 Aug 11:2020.08.07.20170258. doi: 10.1101/2020.08.07.20170258. PMID: 32817976; PMCID: PMC7430621.

43. Debisarun P, Struycken P, Domínguez-Andrés J, et al. The effect of influenza vaccination on trained immunity: impact on COVID-19. MedRXiv. doi:10.1101/2020.10.14.20212498.

44. Horns F, Dekker LC, Quake SR. Memory B cell activation, broad anti-influenza antibodies, and bystander activation revealed by single-cell transcriptomics. Cell Reports. 2020;30: 905-913.
45. Fink G, Orlova-Fink N, Schindler T, Grisi S, Ferrer AP, Daubenberger $C$, et al. Inactivated trivalent influenza vaccine is associated with lower mortality among COVID-19 patients in Brazil. n.d.; doi:10.1101/2020.06.29.20142505.

46. Salem ML, El-Hennawy D. The possible beneficial adjuvant effect of influenza vaccine to minimize the severity of COVID-19 [published online ahead of print, 2020 Apr 22]. Medical Hypotheses. 2020;140: 109752.

47. Li Q, Tang B, Bragazzi NL, Xiao Y, Wu J. Modeling the impact of mass influenza vaccination and public health interventions on COVID-19 epidemics with limited detection capacity. Mathematical Biosciences. 2020;325: 108378.

48. Maltezou HC, Theodoridou K, Poland G. Influenza immunization and COVID-19. Vaccine. 2020;38(39): 6078-6079. doi:10.1016/j.vaccine.2020.07.058.

49. Grech V, Borg M. Influenza vaccination in the COVID-19 era. Early Human Development. 2020; doi:10.1016/j.earlhumdev.2020.105116.

50. Thindwa D, Garcia Quesada M, Liu Y, Bennett J, Cohen C, Knoll $M D$, et al. Use of seasonal influenza and pneumococcal polysaccharide vaccines in older adults to reduce COVID-19 mortality. Vaccine. 2020;38(34): 5398-5401.

51. Paget J, Caini S, Cowling B, Esposito S, Falsey AR, Gentile A, et al. The impact of influenza vaccination on the COVID-19 pandemic? Evidence and lessons for public health policies. Vaccine. 2020;38(42): 6485-6486. 